\title{
الوعي الأمني لدى عينة من أبناء رجال الشرطة
}

\author{
أعراد \\ الباحثة/ عبير محمد فوزى نوفل \\ إسرافـ \\ أ.م. د/ محمد حسينز سعد اللدين \\ أ. د/ أكرم فْتحى زيلهان \\ أستاذ مســاعد عـلم النفس \\ أستاذ ورئيس قسم عـلم النفس \\ كـلـيتمالآداب-جامعت المنصورة \\ كـلـيتتالآداب-جامعت المنصورة \\ المجلت العلميت لكليت رياض الأطفال ـ جامعت المنصورة \\ المجلد الرابع - العدد الرابع

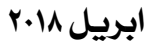




\section{الوعي الأمني لدى عينة من أبناء رجال الشرطة}

الباحثتر عبير محمد فوزى نوفل ["]

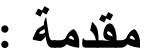

تعد صعوبات التعلم من أهم الهفاهيم التى إنتشرت فى الآونـــة الاخيــرة

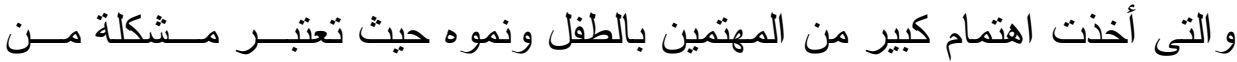

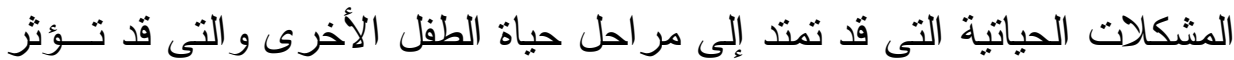
فيها.

\section{المقصود بالوعى الأمنى :-}

تتعدد الإتجاهات في تحديد معنى الوعى الأمنى فيذهب البعض إلـى أن

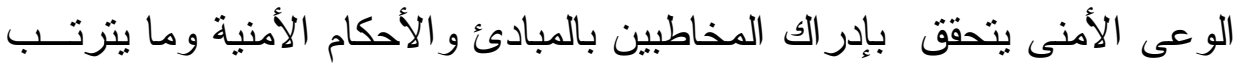

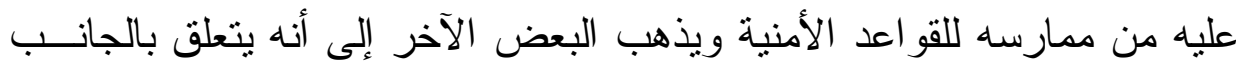

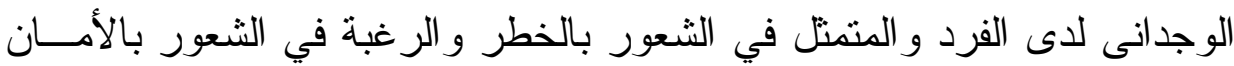

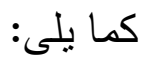

أولاً : - التعريفات التي حددت معنى الــوعى بــإدرآك المخــاطبين

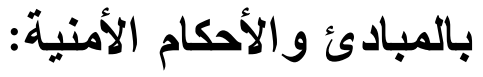

برتبط هذا الإتجاه إلى حد كبير بتحديد مفهوم الوعى الأمنى طبقاً للمفهوم

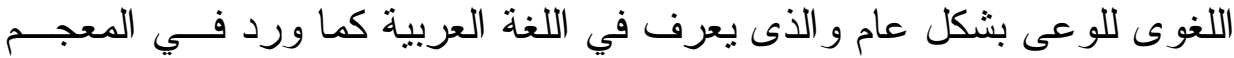

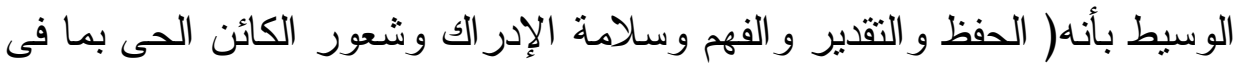

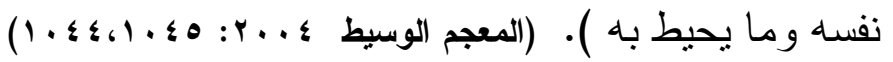

["] [أستاذ مساعد بقسم رياض الأطفال - كليت التربيت النوعيتة - جامعت بنها 
وفى معجم اللغة العربية يعرف أحمد مختار الوعى بأنه (الثعور و اليقظة

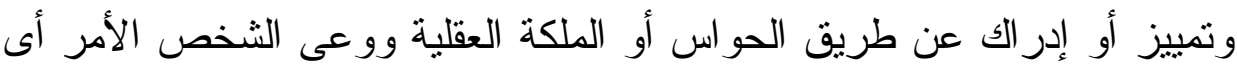



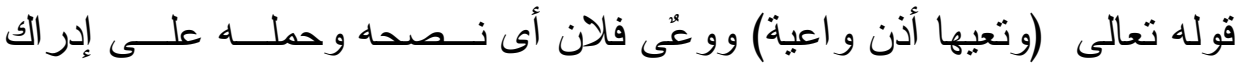

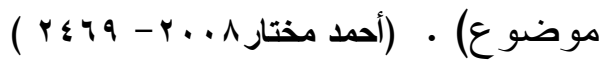
ويرى أثنرف طه ومحمد رفعت أن الوعى الأمني( مصطلح مستمد مـن إنس علم النفس ويعنى إحدى العمليات الذهنية التى تعطى الإنسان القدرة على التبصر

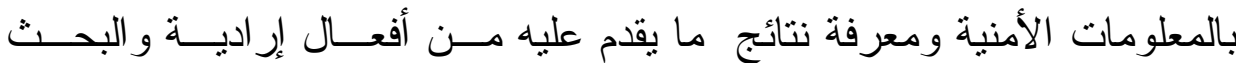

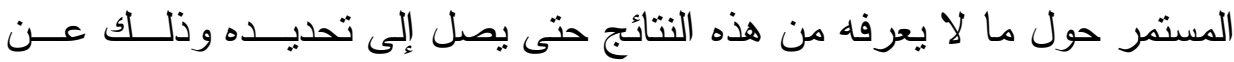
طريق ربط ما تعلمه فى الماضى بوقائع الحاضر ويمد من خلال ذلك نظرة إلى لى لهاه

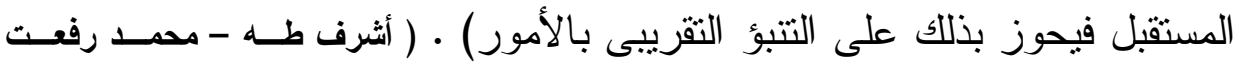

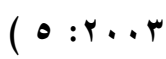

\section{ويعنى هذا التعريف أن :-}

1- الوعى عملية ذهنية يمكن تتميتها r- أن الوعى الأمنى يساعد الإنسان على التبصر بسلوكه ويؤثر في إتجاهاته

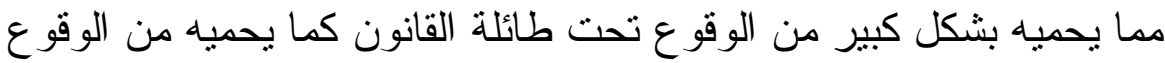

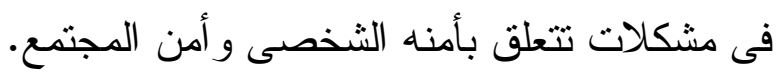

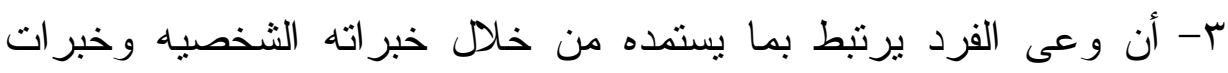
الآخرين من حوله.

ويعرفه نركى الجلعود بأنه (عملية تشتهدف نـشر المعسارف و الحقـــائق

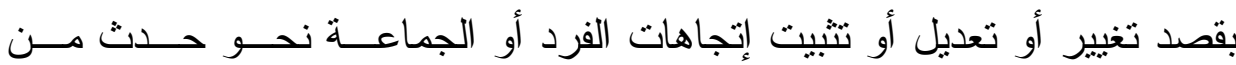

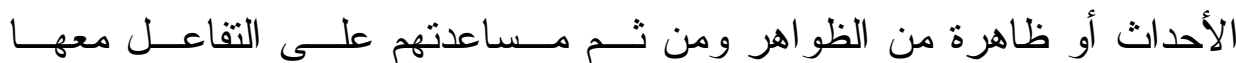


بموضو عية وفى نفس الوقت تقوم بتوجيههم إلى أنسـسب أســاليب الوقايــة مــن التحديات المحيطة بهم لمنعها وللتقليل من آثار ها السلبية المحتملة). وتبعاً لهذا التعريف فإن الوعى الأمنى هو أسلوب وقــائى يهــدف إلــى

التأثير على إتجاهات وسلوك الأفراد والجماعات وتوجيهها نحو الحفاظ علــى

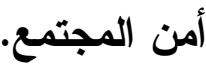

ويعرفه بركه ز امل، بأنه ( إدر الك الفرد لذاته و إدر اكه للظروف الأمنيــة المحيطه بـه وتكوين إتجاه عقلى إيجابى نحــو الموضـــوعات الأمنيــة العامـــه

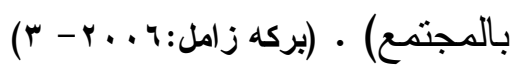

\section{وبهذا التعريف فان الوعى الأمنى يشمل جانبين : -}

أ- إتجاه عقلى بعكس تصور الفرد لذاته و أهمية سيادة الأمن على المو اقف الف

الإجتماعية و الظروف المحيطه به فى المجتمع وتعلم المر اهق لطرق الوقاية من الجريمة بطرق و أساليب تكفل لله ولذويه و أمو الهم الحماية



ب- - إدر الك أهمية المشاركه مع الآخرين فى إتخاذ موقف موحد ضد العبث بالأمن و الإخلال به وتتمية روح المشاركة مما يولد لدى المر اهق سلوكاً

$$
\text { اجتماعياً مر غوباً. }
$$

وتعرفه مارجريت روز بأنه (تثقف المؤسسات للمو اطنين حول السياسات

$$
\text { و الإجر اءات المؤسسية ليمكنهم اكتشاف التهديدات الأمنية التى تو اجههم ). }
$$

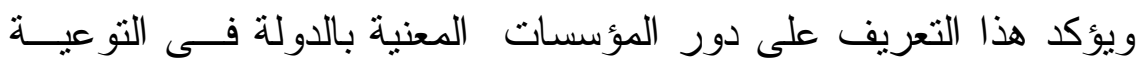

الأمنية التى تساعد المو اطنين على الوعى بالتهديدات المحتملة .

ويتقق التعريف السابق مع تعريف الصالحى بأنه (توعية الناس بالأنظمة و القو انين لخلق و عى جديد فهو يمثل كافة الجهود التى تبذل فـى ســـيل خلــق 
الوعى فى ذهن المو اطن وما تتميز به تلكك الجهود من كونها ذات أفــق واســع

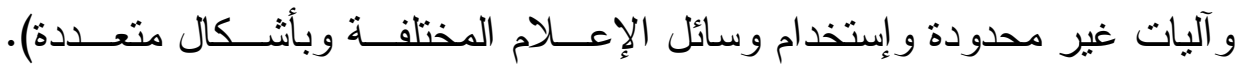
(الصالحى : (1991)

فيثنير هذا التعريف إلى أهمية دور أنظمة الدولة فى نشر التوعية الأمنية

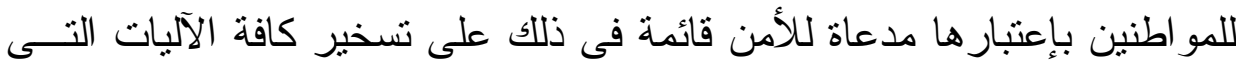
تيسر لها القيام بدورها كوسائل الإعلام وغيرها.

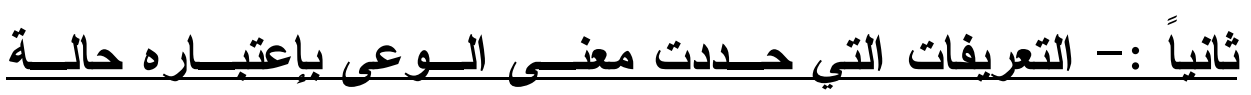

$$
\text { وجدانبة:- }
$$

يعرفه الحارثى بأنه (حالة وجدانية تجعل الثخص يستشعر ما حوله مـن مصادر الخطر و التهديد المحتملة وتدفع به إلى إتخاذ وسائل وبدائل للسلامة منها

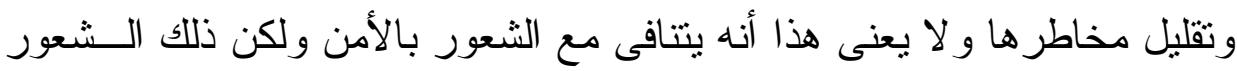

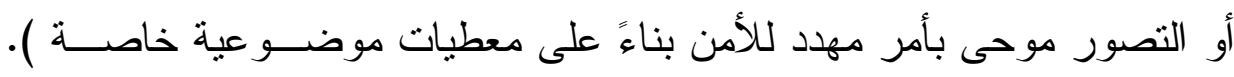

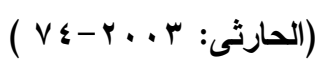

ويركز هذا التعريف على الحالة الوجدانية التى تدفع الإنسان إلى البحــث

$$
\text { عن المعلومات التى نساعده على الحفاظ على أمنه وتوجه سلوكه. }
$$

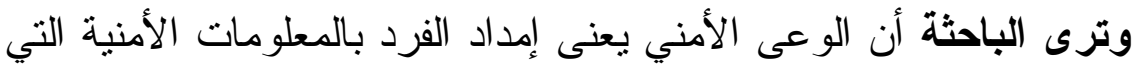

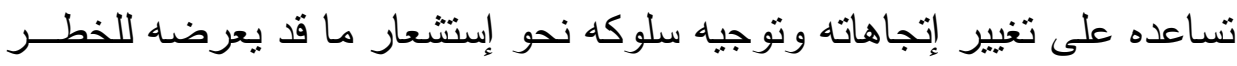

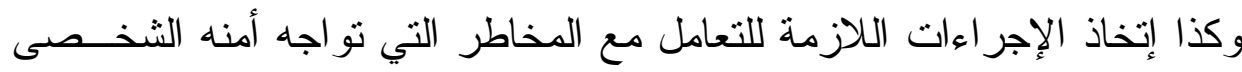

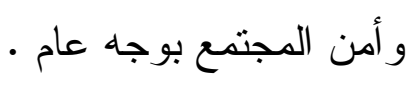

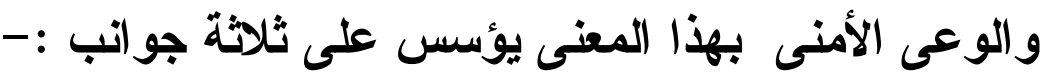

ا ـ الجانب المعرفى و المتمثل في إمداد الفرد بالمعلومات الأمنية لهونية

r. الجانب الوجدانى و المتمنل في تغيير إتجاهاته و إستشعاره الخطر 
r. الجانب السلوكى و المتمتل في إتخاذه للإجر اءات الوقائية و التعامل مع

$$
\text { المخاطر التي تو اجهه. }
$$

وتعرف الباحثة الوعى الأمنى إجرائياً بالدرجة التى يحصل عليهــا المفحـوص

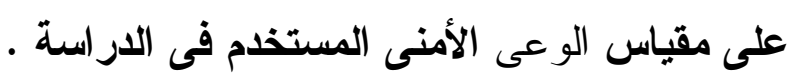

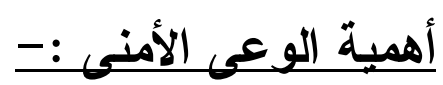

شكل الأمن منذ القدم محوراً أساسياً في حيــاة الإنــسان ، فكــل الآتــار

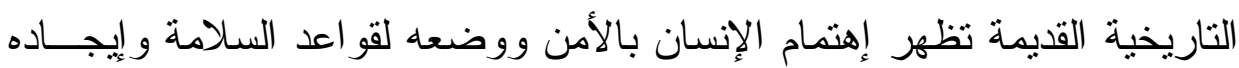

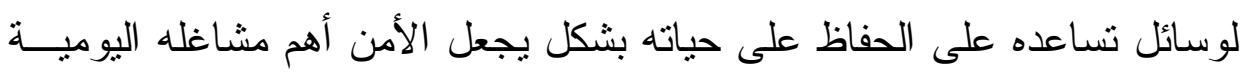

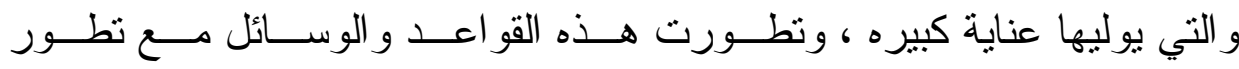

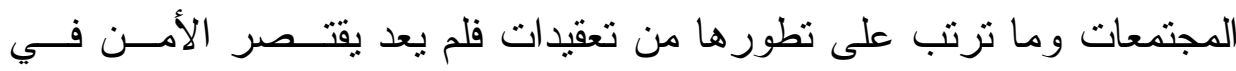



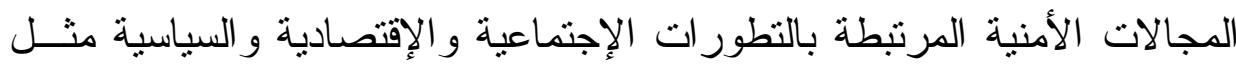
(الأمن الفكرى - أمن الفرد - الأمن الاجتماعى - الأمن المــرورى - الأمسن

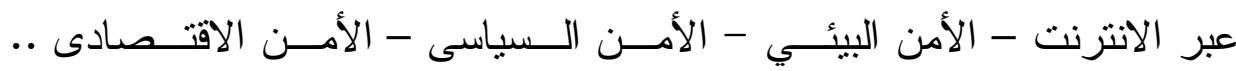

$$
\text { و غير ها). }
$$

ويذكر جمال غيطاس أن الوعى الأمنى يتكون لدى الإنسان من حاجتــهـ



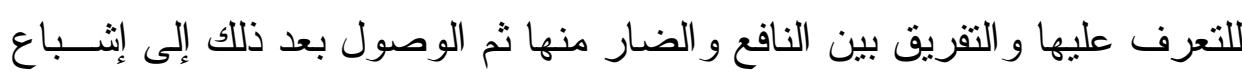

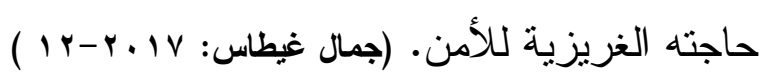

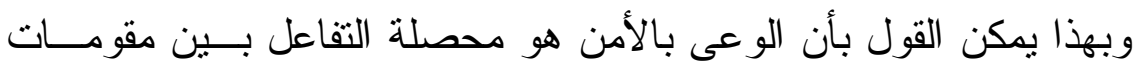

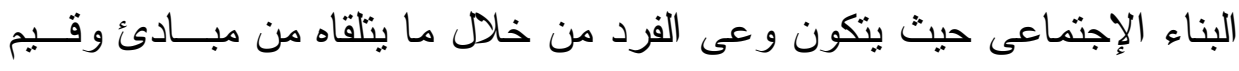




فيه بما يتضمنه ذلك من معلومات يستمدها من خبر اتــه الثخــصية وخبــرات

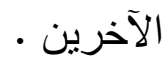

فالأمن أصبح مسئولية قومية يشارك فيها كل أفر اد المجتمع ، وبقدر تز ايد

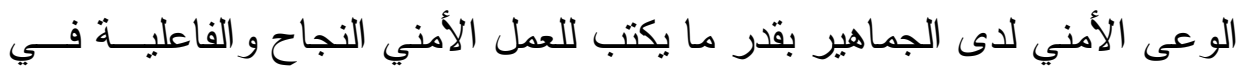

$$
\text { مكافحة الجريمة ونوقى وقو عها. }
$$

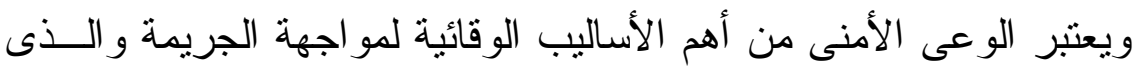

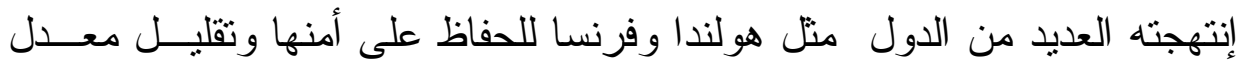
الجريمة ، وذلك من خلال إدداد المو اطنين بمعارف عقليه تشمل مبادئ الحفــاظ

على أمنهم وحثنه على تطبيقها.

فيذكر Geraint Jones ان موظفي الخدمه الألمان ممن تلقــــو ا برنــامج

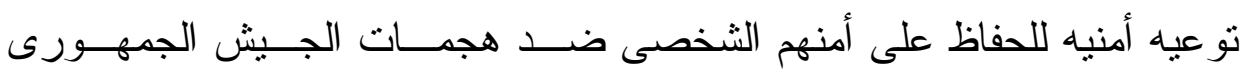

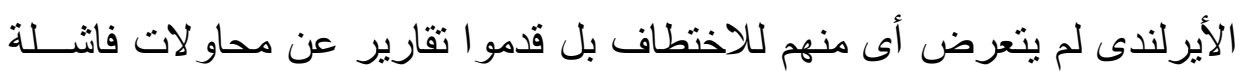

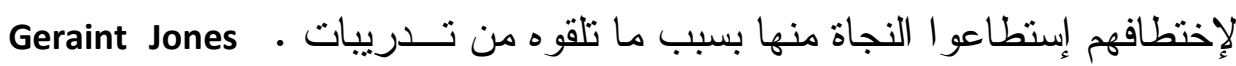

كما تعد تتمية الوعى الأمنى أسلوباً وقائياً يجنب المجتمع ما يلحقـــه مــن

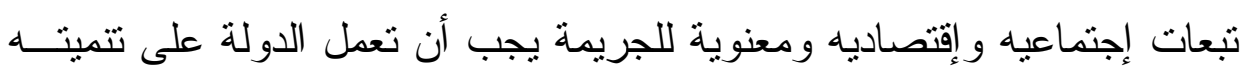
وتطويره بما يخدم مصلحة الأمن و الإستقر ار.




فيرى أثرف طه ومحمد رفعت أن الجريمة ما هى إلا محصلة إيجابيــة

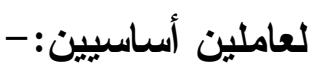
1- العامل الأول يتمنل فى السلوك المنحرف ، الإجر امى للجانى. 
r- العامل الثانى يتمثل فى السلوك الإهمالى الذى يصدر من المجنى عليه.

وهو ما يطلق عليه الفرصة المتاحة حيث أنه لو لا وقوع العامل الثانى ما

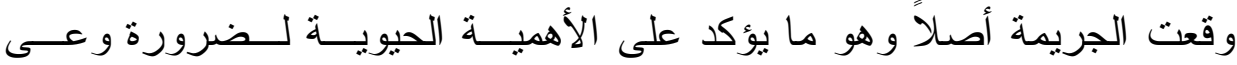

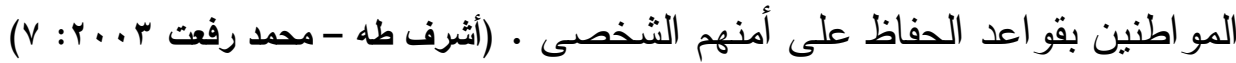

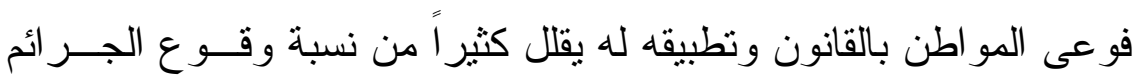
كما أنه السبيل لحثهم على التعاون مع الثرطة . ومن خلال إطلاع الباحثه على الأطر النظريه يمكن توضــيح أهميـة الــوعى

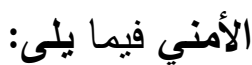

\section{ا - أهمبة الوعى الأمنى للفرد وثتمثل في :-}

- التقليل من المشكلات الأمنية و المخاطر التي قد يقع فيها الفرد وتعرضه

$$
\text { للخطر }
$$

- التقليل من فرص وقوع الفرد تحت طائلة القانون

- تكوين حس أمنى لدى الفرد يجعله بستشعر ما قد يواجهه من مخاطر ويمنحه القدره على نوقع الظواهر السلبية و التصدى لها و العمل على لهى

\section{تقليلها.}

- الإدر الك المناسب بكافة التدابير الوقائية التي تقى الفرد من الجريمة

$$
\text { وتحض على عدم الإنز لاق في بر اثتها أو الوقوع فريسة لها ـ }
$$

- القدرة على تحديد مسار ات التعاون مع الأجهزة الأمنية في مجال الإبـلاغ

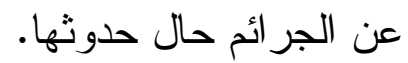




\section{r - أهمية الوعى الامنى للمجتمع}

يعمل الوعى الأمنى بوجه عام على التقليل من الخسائر البشرية والإقتــصادية

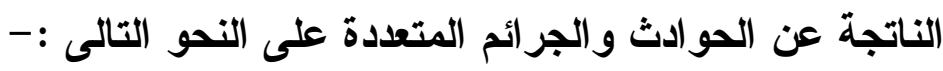
- يعمل الوعى الأمنى الثخصى و المجتمى و القانونى على الثقليل من

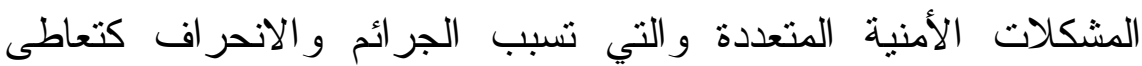
المخدرات و القتل و السرقة و الخطف وغير ها وكذللك سرعة الإبلاغ عن الجرائم أو حتى عن الظواهر المنذرة بقرب حدوثها فوعى المواطنين هو السبيل لتعاونهم مع الثرطة كما أن وعى المواطن بالقانون وتطبيقه له

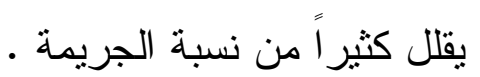
- - يعمل الوعى الأمنى المرورى على التقليل من عدد الحوادث المرورية - يعمل الوعى الأمنى عبر الانترنت على النقليل من عدد الجرائم المستحدثة التي تحدث من خلال الإنترنت متل سرقة المعلومات الثخصية

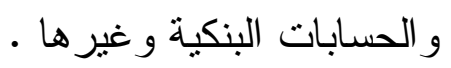

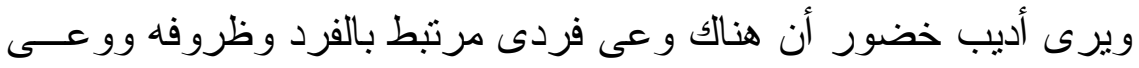

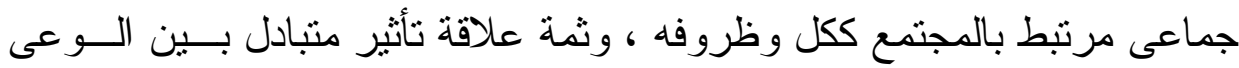

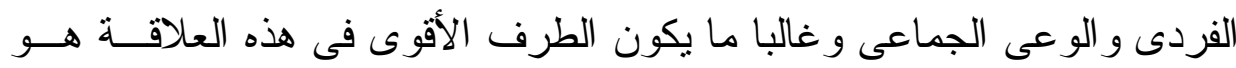



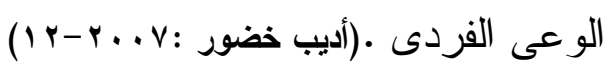

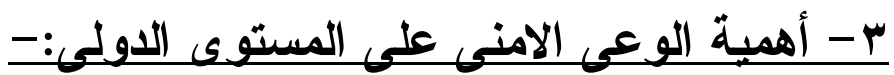
يساعد الوعى الأمنى على تضافر الجهود أمام كافـــة المهـددات للأكــن


الحكومات و المنظمات الأمنية العالميه من جهود و إجر اءات لمواجهة الإرهـاب الإدهاب 
و عدم الإنسياق خلف الثائعات و الأخبار و المعلومات المغلوطة و الني يتم تداولها عبر الإنترنت . ع الإنياق



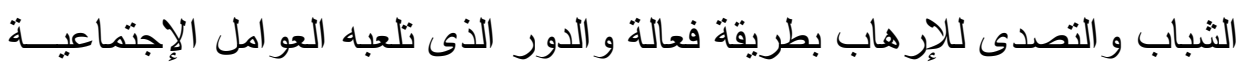

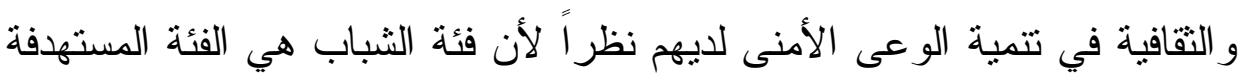

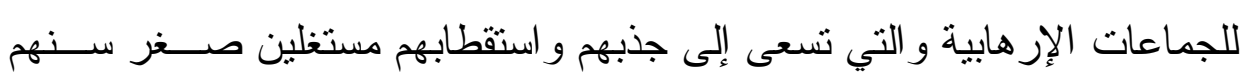

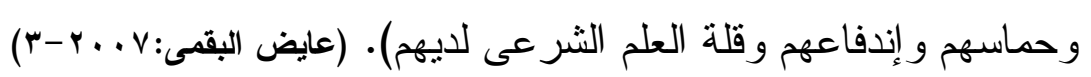

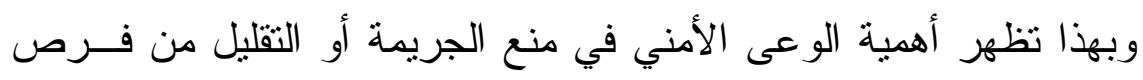

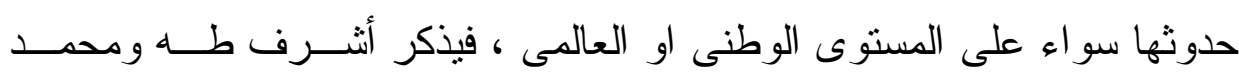

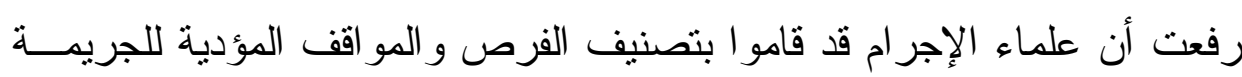

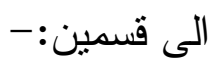

1- الموقف الخامل :- - والذى يستحيل معه تتفيذ الجريمة لأن المنافذ

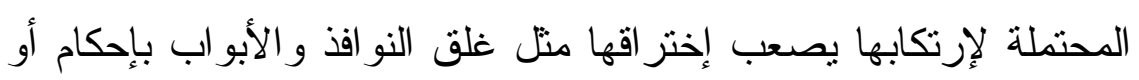

$$
\text { غير ها من إجر اءات الأمن. }
$$

r- الموقف الخطير :-- وهو الذى يسهل معه إرتكاب الجريمة لعدم الجرن



$$
\text { (v:r...r }
$$

وتأسيسا على ما سبق يمكن تحديد أهميه الوعى الامنى بإعتباره جانــب

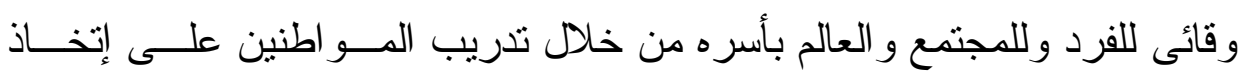

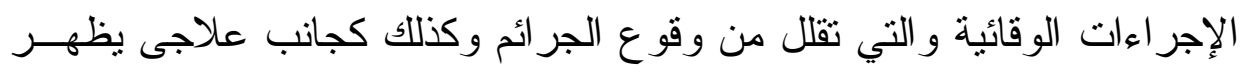
في السلوك التلقائى من المو اطنين لمو اجهة الجريمة . 
ويمكن كذلك تصديد الهذف الأساسي لتتمية الوعي الأمني في الدراســة



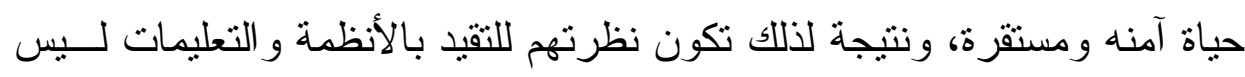

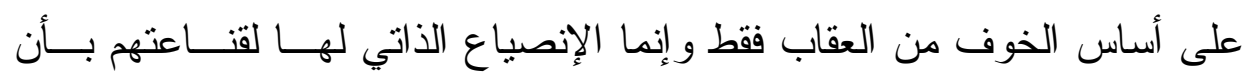

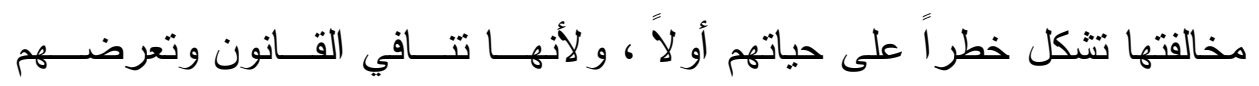
للمساءلة.

\section{خصائص الوعى الأمني :-}

يذكر أديب خضور أن أهم خصائص التوعية الأمنية تتمثل فيما يلى :-

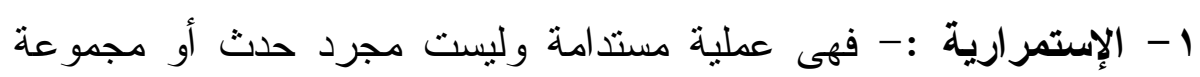

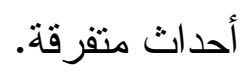

r- المنهجية و الإنظام و التماسك :- فيتحدد أسسها ومنطلقاتها و أهد افها وفق

$$
\text { مناهج وبر امج محددة. }
$$

r-الثمولية :- فالتوعية الأمنية يجب أن تشمل كل المجالات الأمنية

$$
\text { وتنتهدف الوصول لكافة شر ائح المجنمع. }
$$

ـ - التكامل :- فهى عملية تهنم بمختلف الأطراف المعنية بالمسألة الأمنية

$$
\text { وتتطلق من حقيقة أن هذه الأطر اف متكاملة. }
$$

ه- التجدد والتطور :- فعطلية التوعية الأمنية يجب أن نواكبة النب التطور

الإجتماعى وتتتاسب مع المتغير ات الديمو غر افية و الإجتماعية المختلفة.

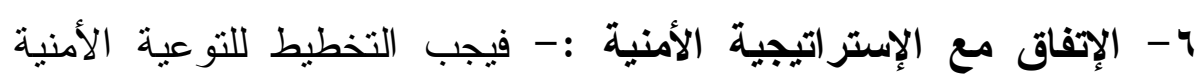

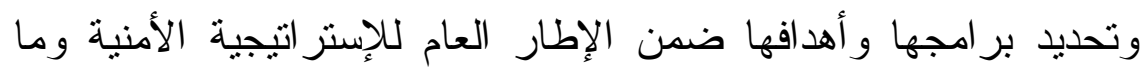

يتفق معها ويسهم في تحقيق أهدافها في مختلف مجالات الحياة الأمنية. 
V- التفاعلية :- فالتوعية الأمنية الناجحة هي التي تعتمد على التفاعل وتحث

المتدربين على المشاركة بما يحقق الأهداف الإستر اتيجية للتوعية الأمنية.

^- أسلوب وقائى طوعى :- فهى لا تفرض بقانون ولكن ينفذها الأفر اد

إنطلاقاً من إعتبار ات و أحاسيس لديهم لدى إستشعار هم بالخطر .

وثرى الباحثه أن أهم خصائص التوعية الأمنية التاجحة ثتمثل

1- مناسبتها للإحتياجات الفعلية للجمهور وللظروف المجتمعيه والسياسية

$$
\text { المحيطه بهم. }
$$

r- مر اعاة أن يكون الأسلوب المقدم في التوعية منتاسب مع الخصائص الديمو غر افيه للمجتمع (السن - المستوى التعليمى و التقافى و الاجتماعى

$$
\text { (الخ ا.... }
$$

r- التجدد والتطوير المستمر بما يتو افق مع التطور ات القانونيه و السياسية

$$
\text { و الإقتصاديه و الإجتماعيه }
$$

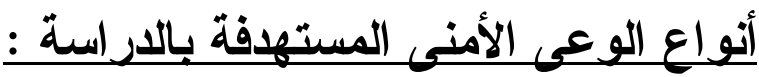

تستهرف الار اسة الحالية الأثكال التالية من الوعى الأمني :-

$$
\text { ا - الوعى بالأمن الشخصى :- }
$$

يعد إسهام المو اطنين فى حماية أنفسهم من الجريمة وتصديهم لمكافحتهــا

$$
\text { هى أحد سبل إسنز اتيجيات منع الجريمة. }
$$

فقد أظهرت در اسة جان يورى بو 199 من خلال نــشر بــر امج الوقايــة

الأمنية لطلبه المدارس و لأصحاب المحلات و الأبنية وحر اس المبانى وبعد إجر اء تقييم مبدئى لهذه البر امج للتعرف على مدى إنعكاسها على معدلات الجنوح فـى 
r مدن هولنديه خلال r سنوات إنخفاض نسبة الجنوح و المشكلات الأمنية بشكل

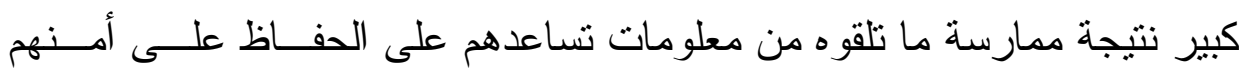

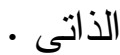

ويذكر روبرت نيلس أن المشكلات الأمنية يحدث معظمها نتيجــة الفهــ

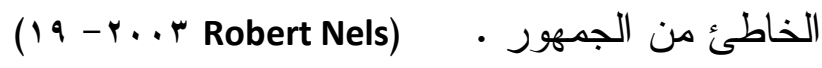

كما يذكر محمود بسطامى أنه بحصر عدد من بتعلمون القـانون ســوياً

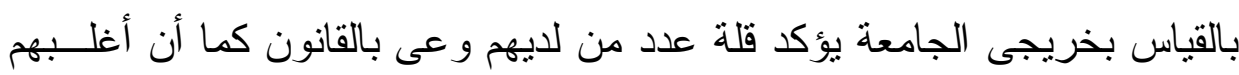

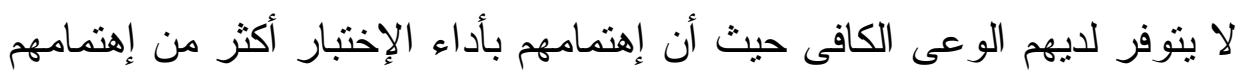

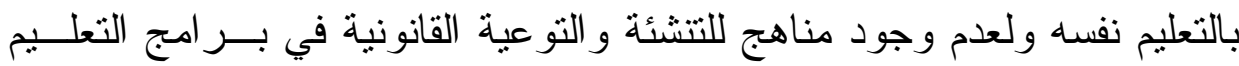

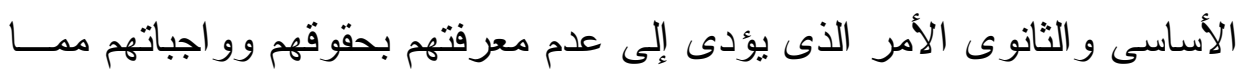

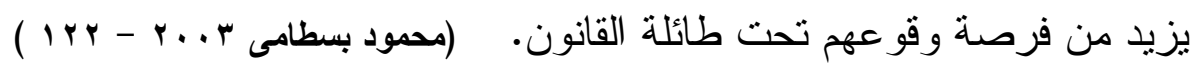
مما يؤكد أن هناك علاقة وثيقة بين إرتكاب الجريمة وسلوك الضحايا ودرجة



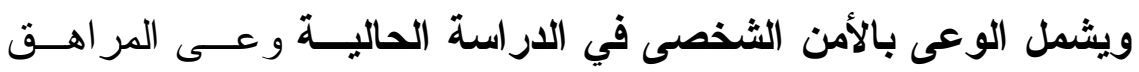

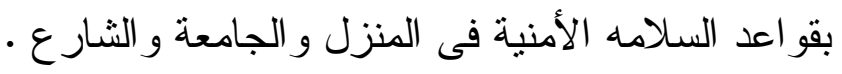
أهداف التوعية بالأمن الثخصى :ترى الباحثة أن من أهم أهداف الوعى الأمني الأتي للمراهقين في الارسة

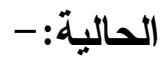

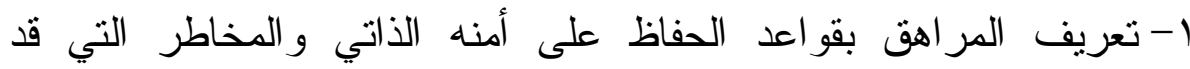
تو اجهه من كو ارث طبيعية أو حو ادث وطرق تفاديها و التعامل معها.

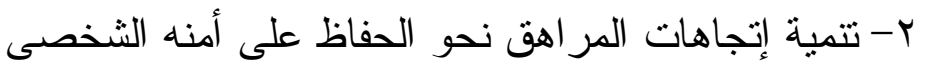


r-تحفيز المراهق على إنخاذ كافة الإجراءات التي تمكنه من

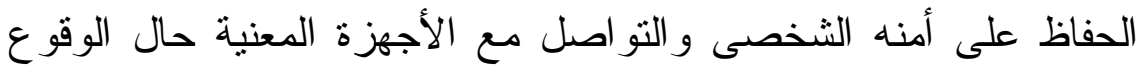

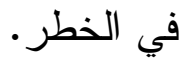

\section{r- الوعى بالأمن المرورى :-}

يرى أديب خضور أن الوعى المروى بمفهومه الــشامل يعنـى (اليقظــــة

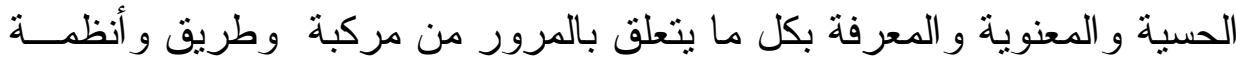

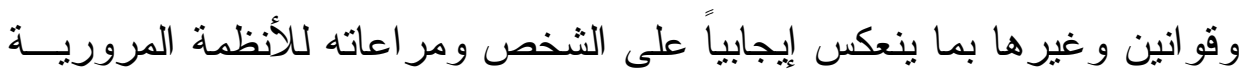

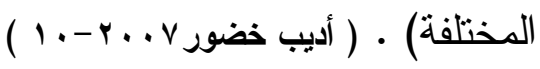

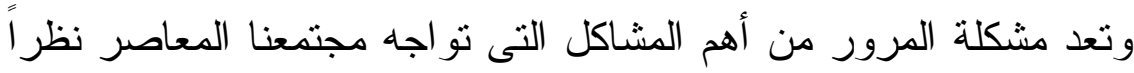

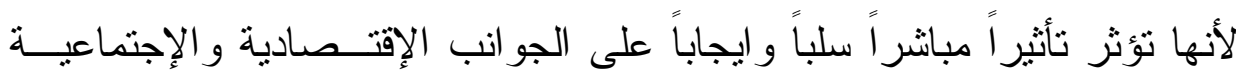

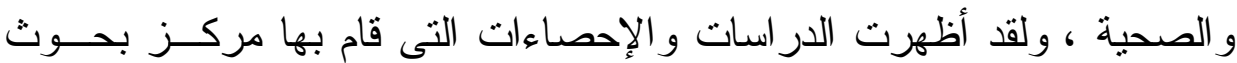

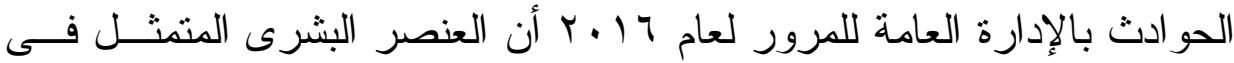

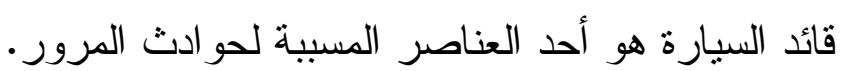

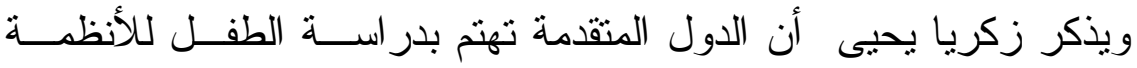

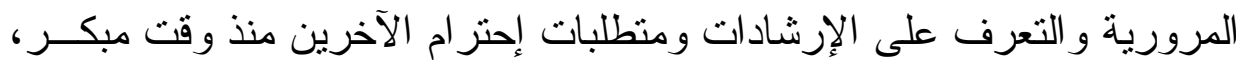
فيتعلم النطبيق لقيادة المركبة داخل الصف الدراسى عبــر إبــتعماله للوســائل

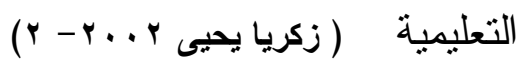

ويقصد بالوعى المرورى في الدراسة الحالية وعى المراهق بالقواعد المنظمة العادية


لإحتر امها للحفاظ على أمنه وأمن الآخرين. 


\section{أهداف التوعية بالأمن المرورى :-}

من خلال الإطلاع على الأطر النظريه يمكن تلخيص أهداف التوعية

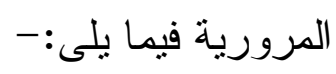

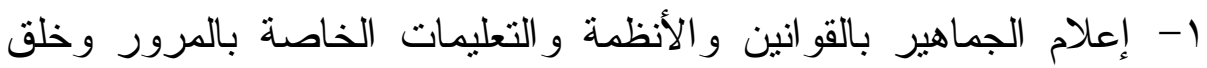

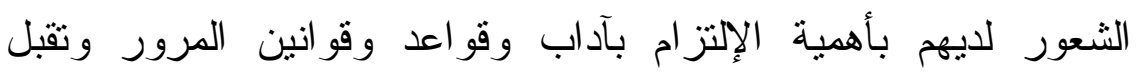

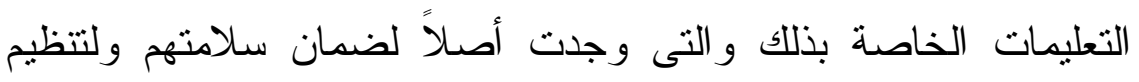

$$
\text { حركتهم على الطرق. }
$$

r- تعديل سلوك مستخدمى الطريق بما ينو افق مع هذه القوانين و الأنظمة

$$
\text { و التعليمات. }
$$

r- حث مختلف الفئات الإجتماعية على تبنى السلوك المرورى الآمن و إبر از



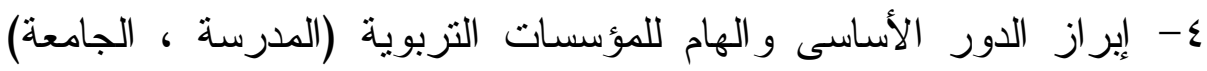
وتفعيل دورها فى مجال التوعية المرورية للطلبة فى كافة مراحل

$$
\text { الدر اسة. }
$$

0- إبر از الجهود و الوسائل و الإجر اءات التى تقوم بها الأجهزة المختصة للحد

$$
\text { من الحوادث المرورية }
$$

צ- تجسير الفجوة بين رجل المرور و الدواطن وخلق تفاهم واحتر ام متبادل

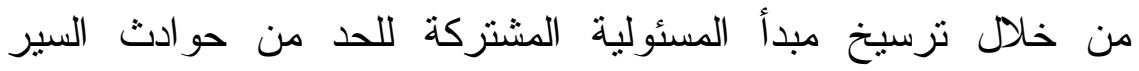

$$
\text { و وآثار ها. }
$$

ويرى أديب خضور أن التوعية المرورية تهدف إلى (تكوين نسق معرفى

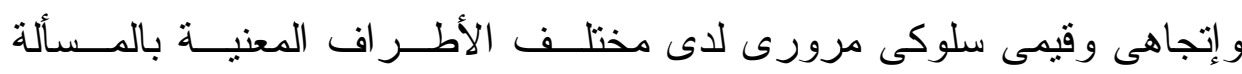

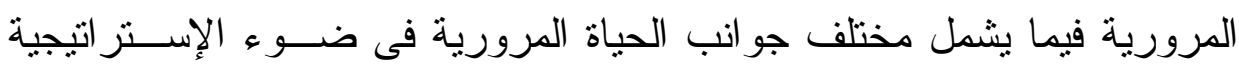

المجلد الرابع


العامة التى تبنتها الدولة و المجتمع وبما يتو افق مع المستوى الفكـرى للـشـر ائح

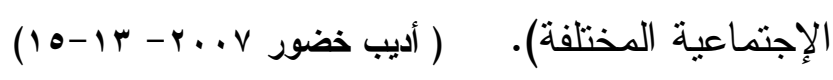

وتزى الباحثة أن من أهم أهداف الوعى الأمني المرورى للمر الهقين في الار اسة الحاليه:

1- تعريف المراهق بالقواعد المرورية و أهية الحفاظ عليها وكذا العقوبات القانونية حال مخالفتها r- تتمية إتجاهات المراهق نحو إنباع القواعد المرورية حفاظاً على أمنه

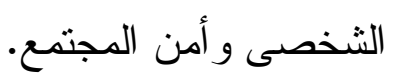
r- تحفيز المر اهق على مر اعاة آداب المرور و إتباع التعليمات المرورية لكى

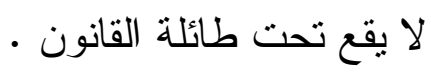

\section{ب- الوعى بالأمن المعلوماتى عير الإنترنت :-}

يذكر خالد ممدوح أن الوعى الأمنى المعلوماتى يعنــى (الإحاطــــة بــأمن

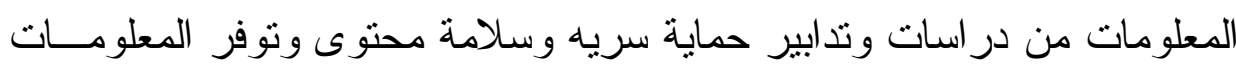



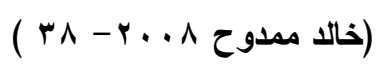

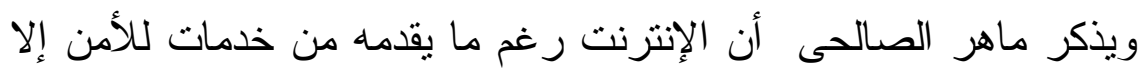

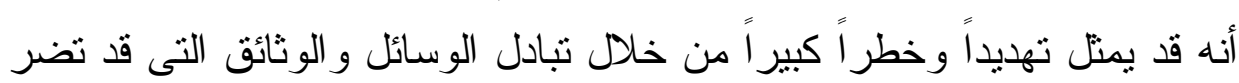

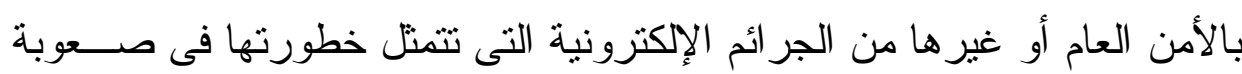


فالجريمة الإلكترونية هى جريمــة تـستهدف الإعتــداء علــى البيانــات

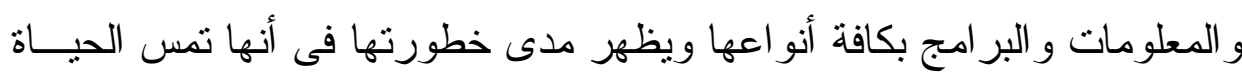

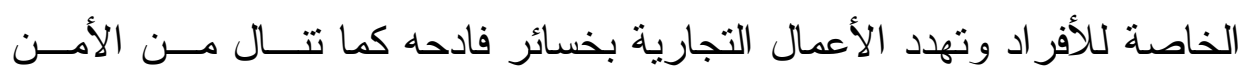


القومى و السيادة الوطنية للدول وتزيد خطورتها مع التقدم التكنولوجى وما يتيحه من إمكانيات تهدد الامن القومى •

وون هذا المنطلق كان لز اما أن يو اكب هذا التقدم فهــم ودر ايــة كـــاملين بالجريمة المعلوماتية ووسائل مكافحتها سو اء من الناحية التقنيــة وهــو عمـلـل المتخصصين فى مجال تكنولوجيا المعلومات باعتبار أن ما يثار من مشاكل عن طريق التكنولوجيا لا يحل أيضناً إلا بواسطة التكنولوجيا أو من الناحية القانونيــة وهو عمل رجال الفقه و القانون • ويذكر عدنان الفيل أن الجريمة الإكترونية تشمل كل من :ا- الوصول إلى المعلومات بشكل غير قانونى كسرقة المعلومات أو حذفها أو تعديلها

r- الوصول إلى الأجهزة الخادمة الموفرة للمعلومات وتخريبها أو تعطيلها r- الحصول على معلومات تغيير عناوين مواقع الإنترنت بهدف إبتز از المؤسسات العامة ع- الكسب غير المشروع من خلال إستغلال تقنية المعلومات منل تزوير بطاقات الإئتمان و إختر اق المو اقع الإلكترونية. 0- إستخدام التكنولوجيا في دعم الإزهاب و الأفكار المتطرفة 7- إنتحال الثخصيه لتحقيق إستقادة ماديه - V الإبتز از و التهديد وتشويه السمعه ^- النصب و الإحتيال كبيع السلع أو الخدمات الوهية ولية

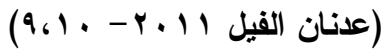


ويعنى الوعى بالأمن المطلوماتى عبر الإتترنت في الدراسة الحالية وعى

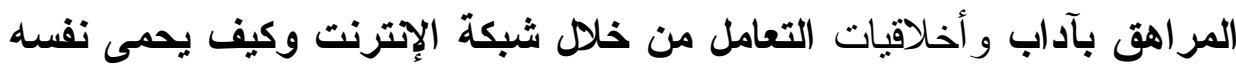
من الوقوع فريسة لمخاطر الإنترنت.

\section{أهداف الوعى الأمنى المعلوماتى عبر الإتترنت :- الإنرست}

يرى تركى الجلعود ان الوعى بالأمن المعلوماتى تتمثل أهدافه فيما يلى :

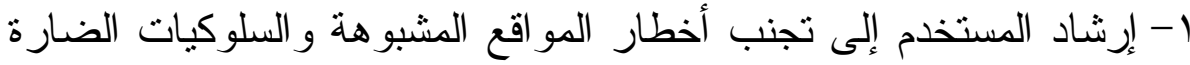

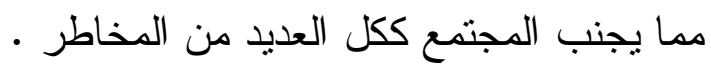
r-تعزيز الإدر الك لدى المستخدم لفرز المعلومات و التمييز بين ما هو حقيقى

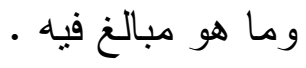

r- تحفيز المستخدم على التواصل مع الجهات المختصة فى حالة التعرض هاله لخطر أو ملاحظته لأخطار تهدد أمن الوطن.

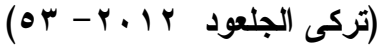

وترى الباحثة أن من أهم أهداف الوعى الأمني المعلوماتى للمــراهقين

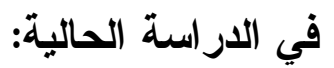

1- تعريف المر اهق بالمخاطر التي من المكن التعرض لها عبــر الإنترنـــــ ليتمكن من تفاديها وكذا طرق التعامل معها حال حدوثها ـ التهرئ.

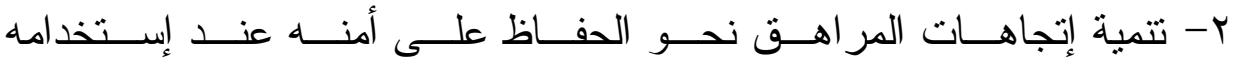

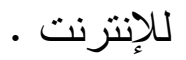
ץ- تحفيز المر اهق على إتخاذ كافة الإجر اءات التي تضمن لــهـ عـــدم الوقـوع ع

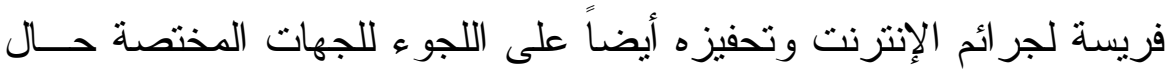
تعرضه لها. 
لا يحدث الوعى الأمنى دفعة واحدة بل هــو مجموعــة مــن المعــارف





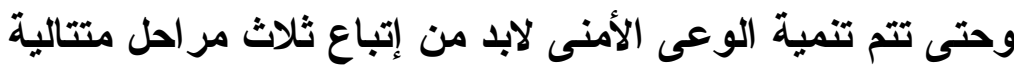

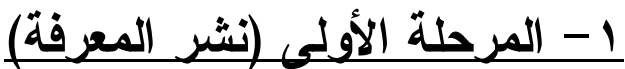
ويقصد بها تغيير المعلومات غير الصحيحة للمسنقبل و إستبد الها بـأخرى صحيحة.

r - المرحلة الثانبة (تغبير الإتجاهات)

وتتمنت فى تغيير الإتجاهات و المواقف غير المستحبة للجمهور المستهدف وتقوية الإتجاهات المستحبة لايه من خلال عرض بـر امج التوعيـة ومناقـشة الجمهور المستهدف.

\section{ب- المرحلة الثالثة (تغيير السلوك)}

وتستهدف تغيير سلوك الجمهور المستهدف بقدر الإمكان بناء على ما تــم

بالمر حلتين السابقتين. (Bottoms,A,E,1990;3-22) ويذكر ذكريا يحيى وأديب خضور وأثرف طه ومحمد رفعت أن الــوعى الأمني يمكن تتميته من خلال عدة وسائل على النحو التالى :1

حيث يتميز الإعلام بسهوله نقله المعارف المختلفة للجماهير في كل مكان ولمختلف الفئات الإجتماعية و الثقافية ويتم ذلك من خلال بر امج خاصة بالتوعية الأمنية وكذلك البر امج الحواريــة و اللقـــاءات العامــة بالمــسئولين و الجمهـــور 
و التقارير الصحفية ومتابعة الحوادث و المقالات و الإعلانات التى تحتـوى علــى

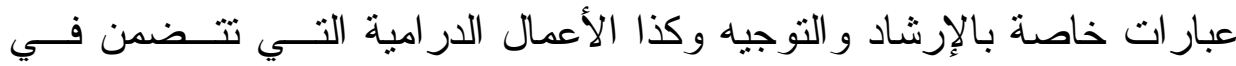
محتو اها تو عيه للمشاهدين.

$$
\text { - : r الصحافة }
$$

حيث تهنت الصحف بنشر أخبار الحوادث و القضـايا الهامـــة و الإجــر اءات

التي تم اتخاذها وهى بهذا تقدم ماده تعليمية للجمهور وبطريقه مبسطه وسلسة . ب- اللقاعات و التدوات :

وتتشمل الندوات و المــؤتمر ات و المحاضـــر ات ، المعــارض التربويـــة ، أمسيات بالمدارس و الجامعات لتوعية الجماهير بالأسباب الحقيقيه لوقوع الجر ائم وكيفية تفاديها و التعامل معها.

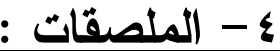

وتشمل الكتيبات و الملصقات و المطويات ، الأدو ات المكتبيــة ، الملابـس و الأدوات ، اللوحات الدعائية بالملاعب و المدارس ، فو اتثر الخدمات المتتوعــة كالبنوك و الهو اتف و الكهرباء و المياه و التي تجذب إنتباه المو اطن وتـــل إلــى مشاعره مما يؤدى إلى تفعيل دوره في مواجهة الأخطار المهدده للمجتمع. (زكريا

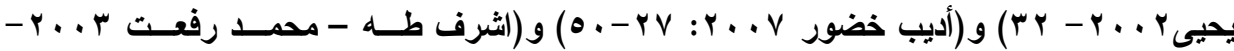

وترى الباحثه أن تتمية الوعى الأمني تستلزم إمداد المر اهق بالمعــارف


كيفية إتخاذ الإجر اءات الإحتر ازيه و التعامل مع الكوارث منل التــدريبات التـي تقوم بها حالياً إدارة الحماية المدنية بوزارة الداخليه من تدريبات إخلاء المدارس 
و الجامعات و التعامل مع الحر ائق و الكو ارث وغير ها مما يساعده علــى تغييـــر إتجاهاته وتوجيه سلوكه نحو الحفاظ على أمنه الذاتي و أمن مجتمعه. دور المؤسسات المختلفة في تنمية الوعى الأمني للمر اهقين :

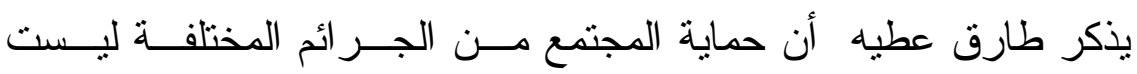

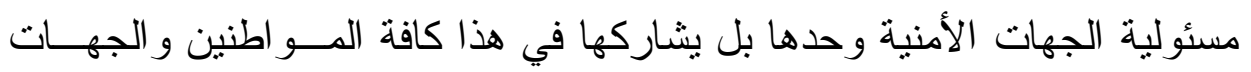



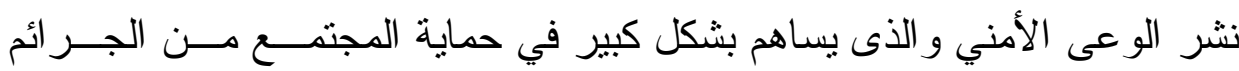

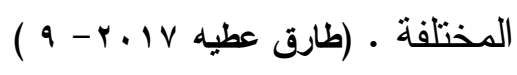
ويمكن إستعر اض دور المؤسسات المؤثره في المجتمع والتي يمكن من خلالها نشر الوعى الأمني فيما يلى: 1- المؤسسات التربويه :--

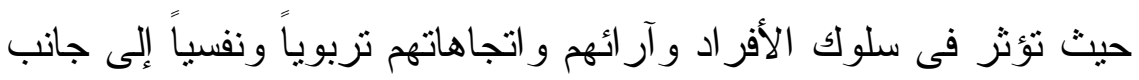





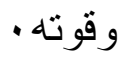

ويتفق العلماء على أن التزبية قوة ضابطة لسلوكبات الأفــر اد إذ بيتخـــها

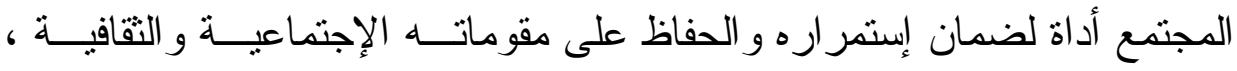

$$
\begin{aligned}
& \text { وتتمتل المؤسسات التزبويه في :- } \\
& \text { أ- الأسرة: - }
\end{aligned}
$$

بإعتبارها المؤسسة التزبوية الأولى في حياة الطفل ويذكر أديب خضور

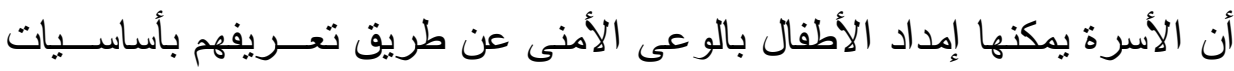


السلامة الأمنية وغرسها في نفوسهم وحثهم على الإعتياد على السلوكيات التـى

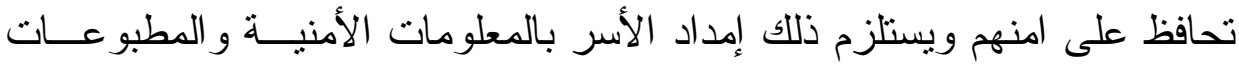

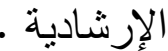

كما يرى جلال عبد الخالق أن ما بستمده الفرد من أســــته مــن توعيـهـ بالقيم الفكرية المستمده من التزاث الاجتماعى للمجتمع تتير لله الطريــق وتعينــهـ على سلوك الطريق السوى و القويم



وعليه فإن للأسرة دور هام وفعال في تتمية الوعى الأمني للفــرد فــي جميع مر احل حياته خاصة في مرحلة الطفولة .

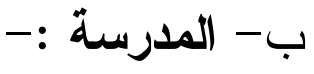

بما تمنتله من خبره ثقافية و إجتماعيه هائلة للطفـلـل فـــي مر احسل حياتــهـ




الآخرين يشكل وعيه ويوجه سلوكه .

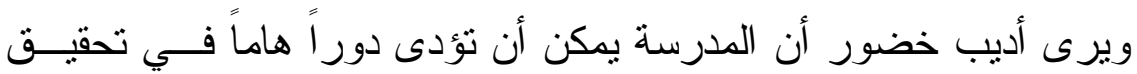

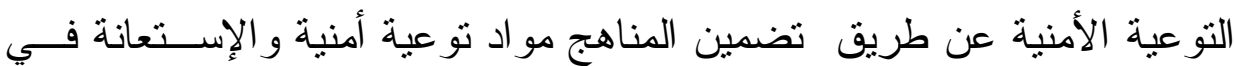
ذلك بالملصقات و المطبو عات و الصحف و الإذاعة المدرسية و الندو ات و الأنسشطة

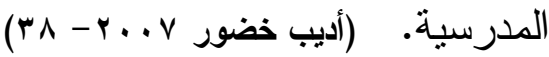

$$
\begin{aligned}
& \text { - : الإعلام }
\end{aligned}
$$

يذكر طارق عطيه أهمية تفعيل سبل وآليات التعاون و التنسيق بين أجهزة الأمن و الأجهزة المعنية بوسائل الإعلام لمتابعة ما يتم الإتفاق عليه فــي مجــال

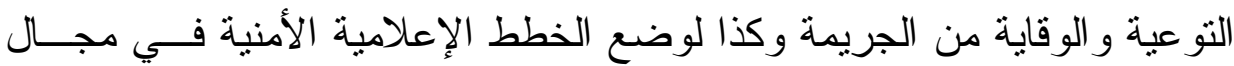




التصدي للمشكلات الأمنية كشكلة الإزرهاب و المــرور و المخــدرات و غيرهـــا.

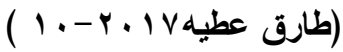
ولذا نجد أنه من الضرورى التتسيق بين الجهات الأمنية و الإعلام بهـدف

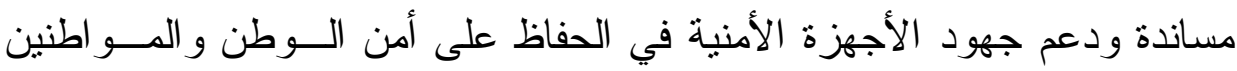
نظر الما يمنلك الإعلام من وسيلة مؤثره على المر اهقين وتحقيق الوعى الأمنى



1- يجب أن يدرك جميع القائمين على العمل الأمنى أنه لابد من نو افر

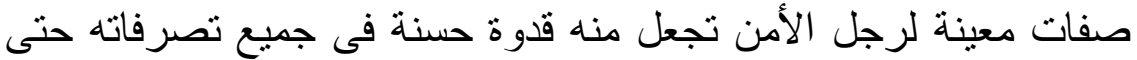
أبسط المعاملات فلا نجده مثنا يسير عكس إتجاه السير أو دون إستخدام حزام الأمن أو بلا رخصة قيادة وما إلى ذلك، لأن متل هذه التصرفات قد

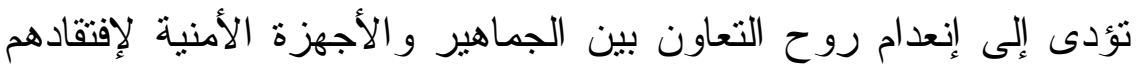
القدوة الحسنة من جر اء تلك التصرفات. r- مشاركة رجل الثرطة فى اللقاءات و الندوات الهادفة إلى التوعية الأمنية فى المدارس و الجامعات و اللقاءات التليفزيونية وغيرها ، وتقوم وزارة

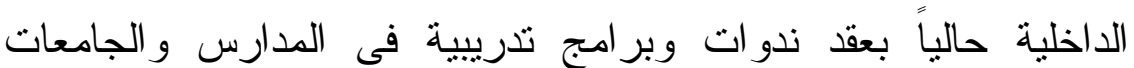
و المؤسسات الحكومية والخاصة من خلال إدارة الحماية المدنية لتوعية

الجمهور للتعامل مع الكو ارث و إدارة المرور لتوعية الجمهور مرورياً. r- ضرورة تفعيل دور الإعلام الأمنى فى نشر التوعية الأمنية للشرائح المختلفة من الجمهور عن طريق الأفلام القصبرة و اللقاءات التلليفزيونية

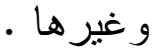


وتأسيساً على ما سبق يمكنتا القول أن التوعية الأمنية مسئولية قوميــة

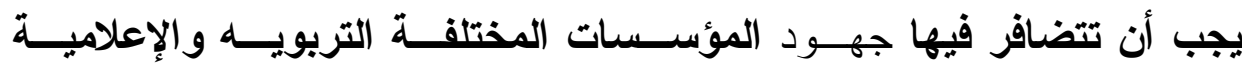

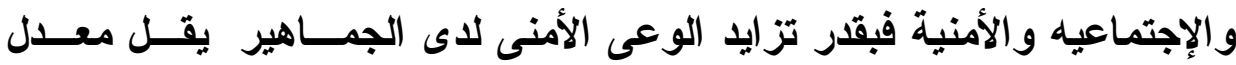


في التصدي لكل ما يهاد أمن المجتمع.

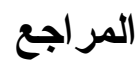

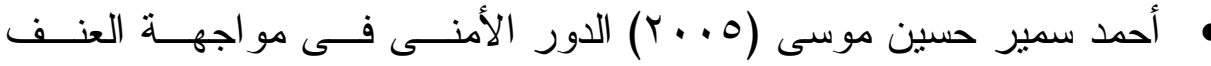
السياسى، دبلوم إدارة الأزمات ، كلية الدراسات العليا.


الر أى العام المصرى وتجسير الفجوة بين الثرطة المصرية والر أى العام دبلوم الأمن العام أكاديمية الثرطة ، كلية الدراسات العليا.

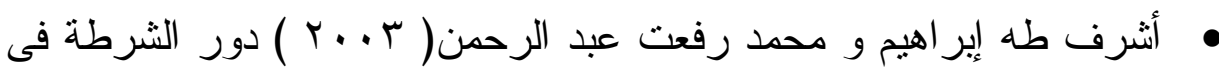

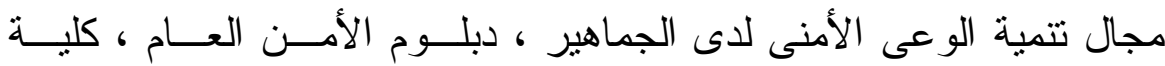


ا المعم الوجىز (1990) مجمع اللغة العربية ، دار التحرير، مصر •



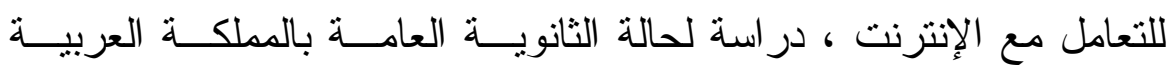

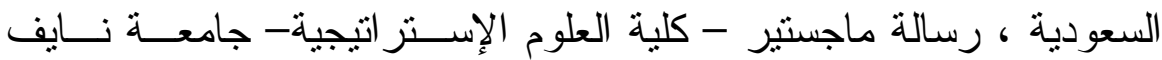

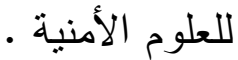

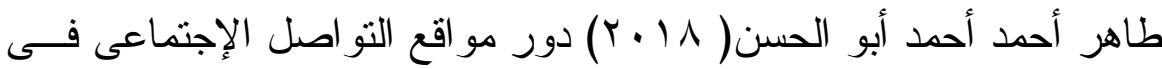

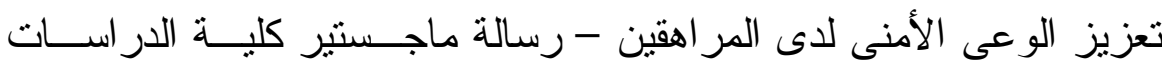

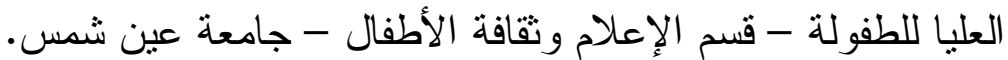






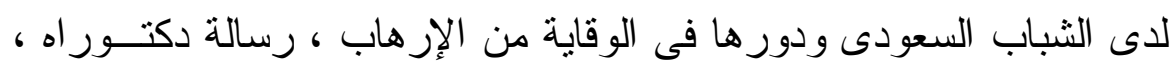

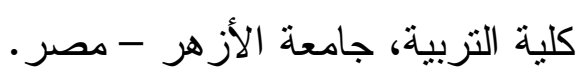

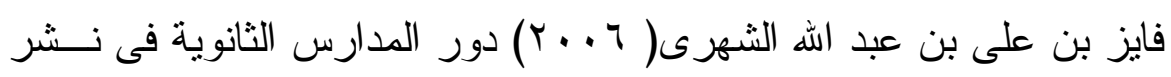

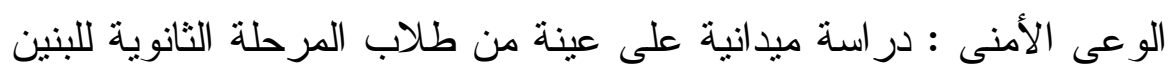



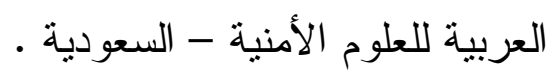

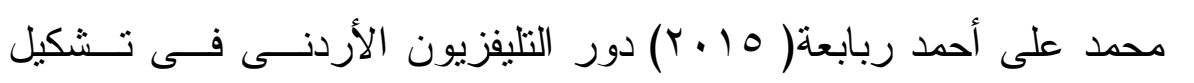

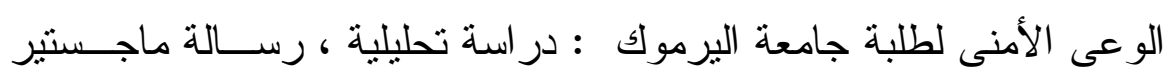
كلية الاعلام 